\author{
Andrzej Harasimiuk \\ University of Warsaw - Faculty of Geography and Regional Studies - Department of Geoecology \\ 00-927 Warsaw, Krakowskie Przedmieście 30 \\ e-mail: A.Harasimiuk@.uw.edu.pl
}

\title{
SOILS AND CHEMICAL CYCLING OF ELEMENTS AFTER LAND USE CHANGES (CASE STUDIES)
}

\begin{abstract}
The process of abandonment of arable land seems to be one of the main factors of changes in landscape and soil properties. This problem occurs on nearly $10 \%$ of arable land in Poland. The natural aspect of transformation is connected with the entrance of birch trees on uncultivated land and the anthropogenic aspect is associated with pine plantations. In the beginning, the appearance of trees on the former arable land changes soil properties because soil (and plant) is the most dependent component of the natural environment. In this paper, the role of birch and pine was analysed in comparison to arable land, abandoned land without trees and birch tree communities of different age. After the entrance of birch trees, soil profiles were enriched in nitrogen and elements such as aluminium, iron, cadmium, lead, cobalt, zinc, which were moved from the sod horizon of soil or come from the atmospheric load and were accumulated in litter or the humus horizon. Compared to arable land, some elements, e.g. calcium had lower concentration under birch trees. In comparison to cultivated land, birch and pine trees made the soil environment more natural, as expressed in the chemical properties of soil.
\end{abstract}

Key words: abandoned land, reforestation, plant and soil relationship.

\section{INTRODUCTION}

Soils and plants are the most dependent components of the natural environment, so they most rapidly react to changes in other components. Human activity in arable areas very often leads to land use changes, specially in vegetation. These changes do not act so strongly as to be able to visibly rebuild the whole natural system, but their results 
are especially noTable in soil. The goal of the study was to determine the trend and the quantity range of its transformation in properties of soil and chemical cycling of elements after land use changes.

A part of the abandoned land was usually covered by a birch tree community (Bernadzki, Kowalski 1983, Szujecki 1996, Grzywacz 2002). That process was natural in same of the aspects connected with reproductive properties of birch (anemochory - light and winged seeds were transported long distances by wind). The birch trees have some positive impact on soil properties. Their roots have sufficient power to perforate soil compaction horizons. This is one of the reasons why birch is implemented as an addition in pine forest plantations. On other hand, pine plantations were still esTablished. Pine trees were a monoculture plantation with a growth problem at the 35-40 year growth period (Rutkowski 2001), when alimentary substances become depleted.

Transformation of soil properties on abandoned land has impact on water and climate conditions (temperature, humidity, wind velocity, evapotranspiration), on landscape structure (higher level of biodiversity, higher level of naturalisation), and on the physical and chemical properties of soil (changes in soil structure, changes of $\mathrm{pH}$, elements regime and concentration in soil profile).

\section{MATERIALS AND METHODS}

Abandoned land in Poland. In the structure of land use in Poland abandoned land is a novelty. It appeared as a problem at the end of the $20^{\text {th }}$ century. In the two decades, the rate of abandoned land in Poland increased from $0.16 \mathrm{mln}$ ha $(1.1 \%)$ in 1990 to $2.30 \mathrm{mln}$ ha $(17.6 \%)$ - in 2002 , and decreased to $1 \mathrm{mln}$ ha (7.5\%) in 2006. Currently it is relatively sTable (Tab. 1).

Areas with the highest rate of abandoned land in Poland (over 30 $\%$ ) are concentrated in few regions (Fig. 1). First is the west and northeast part of Poland. In this area, before Poland's economic transformation in 1989, most of the arable land was under government control and was concentrated in large-area farms. This form of management collapsed after 1989 and the rate of abandonment increased rapidly and was mainly determined by economic factors. Second is the central part of Poland which has poor soils. In this case, natural and economic conditions were equal factors. In the third region, i.e. the southern 
part of Poland, the rate of uncultivated land usually was relatively higher then in other parts of Poland and was generated by the highest rate in the mountain and industrial areas.

Tab. 1.

Abandoned land in Poland

\begin{tabular}{|c|c|c|}
\hline \multirow{2}{*}{} & \multicolumn{2}{|c|}{ Abandoned land } \\
\cline { 2 - 3 } & $\begin{array}{c}\text { Area } \\
\text { (mln ha) }\end{array}$ & $\begin{array}{c}\text { Rate in arable land } \\
\%\end{array}$ \\
\hline 1990 & 0.16 & 1.1 \\
\hline 2000 & 1.67 & 9.2 \\
\hline 2002 & 2.30 & 17.6 \\
\hline 2005 & 1.03 & 7.9 \\
\hline 2006 & 0.98 & 7.5 \\
\hline
\end{tabular}

Source: GUS (Central Statistical Office)

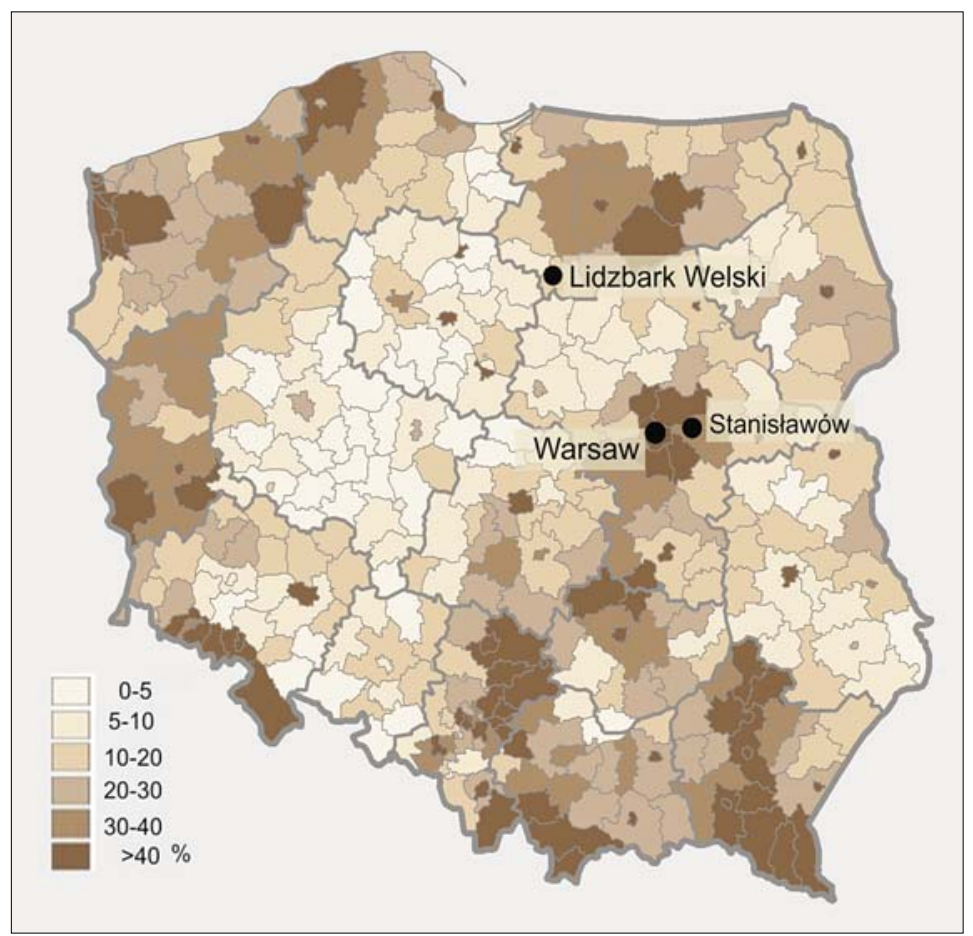

Fig. 1. The rate of abandoned land in Poland in 2002 (source: Internetowy Atlas Polski, IGiPZ PAN, http://maps.igipz.pan.pl/atlas/home_pl.htm, partially changed) 
The research comprising the issues discussed above was conducted in two sites. First in „Stanisławów”, about $40 \mathrm{~km}$ east of Warsaw and second in „Lidzbark”, near Lidzbark Welski. The studies focused on the impact of birches and pines on the chemical properties of soil. The site to the east of Warsaw is a sandy area, covered by podzolic soils, used as arable land. Among farm land there are small patches of pine plantation and birch tree communities. The site near Lidzbark Welski is a glacial loamy area covered with a sandy deposit and cambisols as the dominant soil type.

Comparative studies was applied as the research method. The research plots were located in different land use conditions - cultivated land, arable land, pine plantations and spontaneous genesis birch tree communities. The physical environment conditions inside research sites (surroundings Warsaw and Lidzbark Welski) were relatively similar because of small distances between research plots.

In the field and laboratory work standard soil-geochemical methods were used. The probes of soil horizons, litter in different stages of decomposition and leaves from birch and pine trees were analysed.

\section{RESULTS AND DISCUSSION}

Vertical profiles of elements under birch tree communities (Stanisławów case study). The entrance birch trees on abandoned land make soil more acid (average one $\mathrm{pH}$ units) in upper soil horizons. According to that, it can be said that, birch trees make the soil environment more natural as compared to arable land (Hrdicka, Kula 2001). Most differences were found in upper soil horizons. They were enriched by nitrogen and elements such as aluminium, iron, cadmium, lead, cobalt, zinc, which were moved from soil or come from the atmospheric load and were accumulated in litter or humus horizon (Fig. 2).

In thesoil profile, the maximum of nitrogen was moved from the humus horizon to the sod horizon. Year by year, nitrogen was accumulated under birch trees communities and removed into the arable land condition, on other side.

Compared to arable land, some elements, for example calcium, had a lower concentration under birch trees. The contrast of element concentration in soil between the upper soil horizons (litter and humus horizons) and the underlying horizons is lower under birch communi- 
ties and concentration data are more regular in the vertical profile. Magnesium and phosphorus were especially accumulated in birch leaves and in the litter horizon.

After several years without fertilization, the relationship between elements changed. In the early stages (up to 10 years), in the litter horizons, the potassium level was greater than calcium, later - the calcium level was greater than the potassium level. In the research area conditions, potassium looks like an element which is in short supply and which can determine the limitation for tree growth.
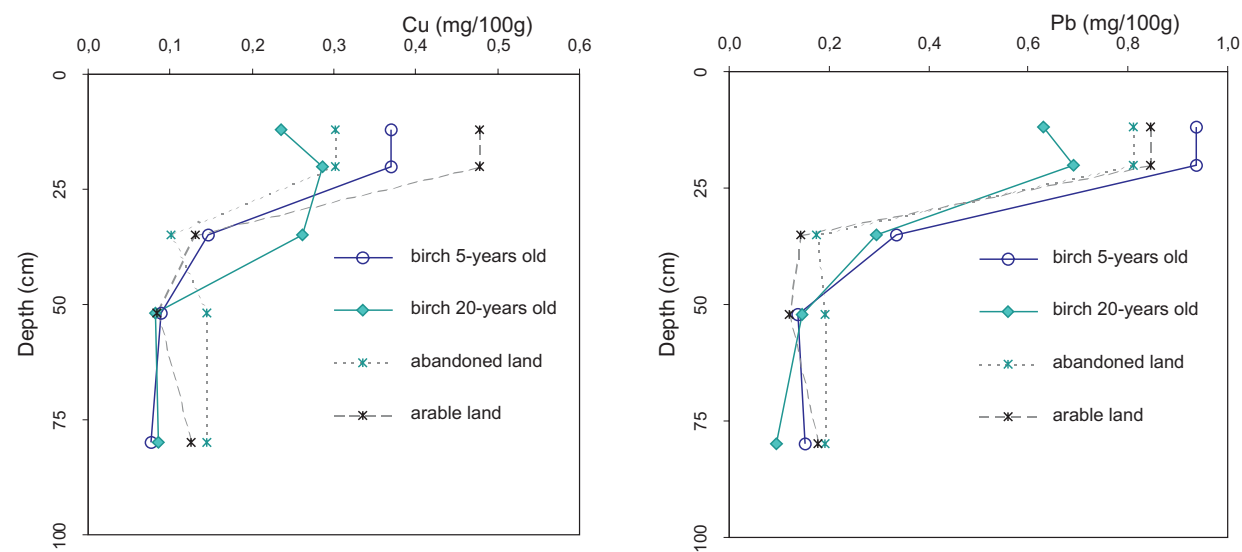

Fig. 2. Vertical profile of $\mathrm{Pb}$ and $\mathrm{Cu}$ in soil under different land use types

On abandoned land birch trees change the chemical regime of landscape. In comparison to arable land, the output of elements is minimized and they are accumulated in plant material, litter and soils horizons. Such a process may be observed in concentrations of elements in different areas of physical environment.

Arable land versus abandoned land and post-abandoned plant communities (Lidzbark case study). In this case, the results of land use changes are expressed in higher concentration of organic matter in surface soil horizons. The nitrogen content in pine litter was on the level of $1.2 \%$, in birch leaves $-1.4 \%$, and was $2-3$ times higher than in arable and abandoned land. Phosphorous was also concentrated, especially in pine needles (1000-1500 mg/kg) and in birch leaves (1300 mg/kg) but in their litter horizons was only $200 \mathrm{mg} / \mathrm{kg}$, however on arable and abandoned land areas $-500 \mathrm{mg} / \mathrm{kg}$. Phosphorous has 
a similar vertical distribution as potassium. The latter's content in abandoned land $(1900 \mathrm{mg} / \mathrm{kg})$ was twice higher than in arable land.

The matter migrations of conditions determined by soil reaction $(\mathrm{pH}(\mathrm{KCl}))$ connected with pine plantation were more acid $(\mathrm{pH} 4.0)$ than in abandoned land $(\mathrm{pH} 4.5)$ and birch tree communities $(\mathrm{pH} 4.2$ and birch leaves 5.5). Only on arable land soil reaction was similar to that of pine plantations. In such a condition, heavy metals were moved into the biogeochemical cycle. They were specially concentrated in pine needles and birch leaves (concentration 10-40 times higher then in soil horizons). Manganese was the element, which mostly differs in the pine and birch habitats (in pine needles the concentration of manganese was twice higher than in birch leaves).

Soil cultivation lasting many years leads to negative changes in the soil profile. In physical properties, this is manifested by the occurrence of the so-called plough sole (a compacted layer at the depth of 30-50 $\mathrm{cm}$ ). Arborescent species occupying former farmlands show a varied capacity to penetrate this layer. Pine trees handle this situation rather poorly, and as a result are forced to expand their roots horizontally, within the former ploughed genesis humus layers. This leads to a reduced use of nutrients and the appearance of degradation symptoms in the pine monocultures which are 30 or 40 years old (trees fall-out, root fungus). There is no problem of compacted layer in the case of spontaneous occupancy in former farmlands by birch trees or broadleaf additions in pine plantations (mainly oak), where tree roots go deeper, beyond the compacted layer. In such a situation, soil resources are more efficiently used, with a lower incidence of tree diseases.

Conducted research pointed out the trend of chemical transformation in soils caused by land use changes. Soil profiles can be permanently transformed if tendencies of increasing abandonment would be continued. It can also react in matter cycling in local watersheds. The positive influences are expressed for example by increasing organic matter and intensification of the biological cycle. The negative consequences are connected with putting heavy metals into the geochemical cycle.

\section{CONCLUSIONS}

After abandonment, 10-year old birches already were nearly a fully structured community. This appears in the matter budget (trees return 
significant elements to the soil. In earlier stages birch trees grows rapidly and the soil loses numerous of its elements).

Birch trees and a limited part of the pine plantation consume elements, which are outside the root zone in arable land utilization.

The birch entrance allows for the appearance of spices which are suiTable to the environmental condition, which alters the soil nutrient pool, their cycling and transforms the geosystem into a quasiequilibrium state.

The abandonment accelerates accumulation of such biophilous elements as nitrogen and potassium in the soil profile.

Especially decrease of the nitrogen content and growth of the trace elements in upper soil horizons are indicators of the initiated naturalization process.

At the moment, abandonment and reforestation are important factors of landscape and soil changes.

\section{REFERENCES}

Bernadzki E., Kowalski M., 1983, Brzoza na gruntach porolnych [Birch in Former Farmlands; in Polish], Sylwan, 127, 12.

Grzywacz A., 2002, Problemy zalesień w wielofunkcyjnym rozwoju obszarów wiejskich [Afforestation Issues in the Multifunctional Development of Rural Areas; in Polish]. Post. Nauk Roln., 3; 15.

Hrdlicka P., Kula E. 2001, Macroelement content in leaves of birch, Journal of Forest Science, 47, 3.

Rutkowski P., 2001, Problemy doboru składu gatunkowego do zalesień gruntów porolnych [Problems of Species Selection in Afforestation of Former Farmlands; in Polish], Roczniki Akademii Rolniczej w Poznaniu, Leśnictwo, 39, 233.

Szujecki A., 1996, Ekologiczne aspekty odtwarzania lasu na gruntach porolnych [Ecological Aspects of Forest Regeneration in Former Farmlands; in Polish], Prace IBL, series B, 27.

English translation: Matgorzata Mikulska 